\title{
Promoting Transfer of Learning across Complex Scientific Domains of Knowledge
}

\author{
Safa Zaid El-Kilani, Adnan Doulat, Mansour \\ Wreikat University of Jordan, Jordan
}

\begin{abstract}
This study explores the efficient way to restructure students' misconception in complex domains of knowledge, in which such restructuring would allow transferring students' conceptual knowledge into other related complex domains. The sample consisted of 16 graduate students studying a course in developing curriculum. Those students had been assigned randomly into two groups (8 students each).
\end{abstract}

\section{Introduction}

One goal of science education is acquiring sound conceptual knowledge about the world through the formulation of relationships among ideas - meaningful learning Ausabel [1]. However, the findings of empirical research show that the accomplishment of such goal is so difficult because students' theories about how the world works conflict with their scientific understanding, students' naïve idea in complex domain of knowledge works as a critical barriers that hinder further learning in many other related domains, and that such naïve perceptions are characterized by having a high degree of coherency, Smith, Blakeslee, and Anderson [12], Pocov' [9], Gomez, Benarroch, and Marin [6], Nussbaum and Novak [8].

Many approaches had emerged since the late seventies to solve this problem: The Piagetian' approach adopts constructivist frame work as described by Posner et al [10]. They used cognitive conflict strategies consisted of engaging students in Socratic type dialectic dialogue in order to make conceptual change. Carey [3] considers that the focus should be on how having the concepts in a particular domain actually affects transferring of reasoning to other complex domains (statable knowledge) - meta-cognitive skills by Brown et al. [2], history of science passes through a series of revolutionary constructions, understanding how the explanatory system changed through different stages, and how early scientists assign the proper idea that allows generation of the others, would be of great help to allow the transfer of restructuring from one particular domain of knowledge into other related domains. Zaid [14] showed that such method succeeded only with students who depend on logical reasoning in understandings; the approach did not succeed with those who depend on their articulation for the scientific sentences while misunderstood their metaphoric meanings. Strike and Posner [13] show that the epistemological approach proved to be difficult for students with short span, low motivation and less interested in the nature of knowledge.

The ontological approach focuses on how students perceive reality, students have difficulty learning certain scientific concepts because there is a mismatch between the categorical representations they bring to an instructional context and the ontological category to which the science concept truly belongs, understanding complex domains of knowledge could be achieved by letting students comprehend the ontological differences between the levels of a complex phenomena and their characterization, such comprehending would provides a theoretical lens to overcome a conceptual obstacles that need to coordinate and integrate knowledge about ontologically distinct entities; those ideas which relate to children's natural framework theories provide a generative foundation for further learning (Duncan and Reiser [5], Chi, Slotta and de Leeuw [4], Kang [7]). However, exploring students' conceptual understanding and conceptual growth using ontological approach shows a consistency of patterns about the difficulty students find; students initially gave evidence of scientifically valid knowledge structures but then regressed to earlier primitive levels of understanding (Shymanasky et al. [11]).

The complex topics that were a target of investigation in most traditions of research about students' misconceptions are those related to kinetic energy, particulate nature of matter, light and heat, conservation of matter and energy, gene, ecosystem, plant nutrition, photosynthesis, metabolism, and energy transfer. The study proposes that by electing the key phenomena that opened the investigations in many complex domains of knowledge in the history of science- the original source of organic material in living organisms, make students aware of their alternative conception about, and then presents the scientific reasoning for the sequence of event related to the phenomena in linear narrative systematic way, such method would lead to automatic restructuring for students' coherent alternative conceptions in other related complex domains related to the core 
issue- conserving of matter and energy. The sample was consisted from 16 graduate students studying a course in curriculum and instruction, assigned randomly into two groups (8 students each).

\section{Analysis}

The two groups of students were pretested by open ended questions about two different phenomena related to understanding conserving of matter and energy in organic material. The first group had been questioned about the substance that counts to the growth of plant. This phenomenon had been targeted by questions in the history of science, which leads to other investigations regarding conserving of matter and energy issues; the second group of students questioned about how the candle lost its substance during its lightening. This is an everyday life phenomena related to conserving of matter and energy issue. The result of the study shows that the first group of students had misconceptions regarding the cause of plant growth, believing that the substance of plant comes originally from organic compounds in the soil (beside water); the result also shows that the second of students had misconceptions regarding the way candle lost its substance, confusing the chemical change (burning) by physical change (melting). They believed that the candle lost its substance during lightening by melting. The restructuring of first group misconception regarding the plant growth had been accomplished by first; let them being aware of their naïve conceptions, then, the correct scientific ideas presented to them in a linear systematic hierarchical way by connecting the issue of absorbing minerals and water from the soil by the mechanism of photosynthesis and the components material of organic compounds. The restructuring of the second group misconception was accomplished by engaging them in dialectic Socratic type dialog, by making students aware that melting material does not equal in quantity to the material that is lost during candle's lightening, and candle's thread would take less than minute if it is burned without being connected to the candle's wax. Both groups were post tested using open ended questions regarding many phenomena related to conserving of matter and energy issue in organic material: the substance of plant growth, the loose in candle's material during its lightening, the loose of body material during exercise, the ultimate destiny of decay materials, and nutrient cycling.

\section{Conclusion}

The results of the study show that seven out of eight in first group of students succeeded in transfer their understanding about plant growth to other related complex domains of knowledge, while engaging the second group of students in just Socratic type dialog about marginal phenomena candle's lightening- did not promote the transfer of their understanding into other related complex domain of knowledge. The result of study shows that history of science could be used to guide the election of revolutionary type of knowledge that lead to other investigations in related complex domain of knowledge, let students being aware to their misconceptions about it, and then presenting the correct scientific idea about the whole issue in a linear systematic hierarchical way to allow the transfer of students understanding to other related complex domains of knowledge.

\section{References}

[1] Ausubel, D., (1963) "The Psychology of meaningful verbal learning. New York: Grune \& Straton, Inc.

[2] Brown,A., John, B., Robert, F., \& Joseph, A. "Learning, Remembering and Understanding”, Handbook of Child Psychology, New York: Wile (1983).

[3] Carey, S., (1984), Reorganization of knowledge in the course of acquisition, Unpublished paper, Massachusetts Institute of Technology.

[4] Chi, M., Slotta, J., \& de Leeuw, N., (1994) Conceptual change within and across ontological categories; Examples from learning and discovery in science. In R. Giere (Ed.), Minnesota studies in the philosophy of science (Vol 15, pp. 129-186) Minneapolis/St.paul, MN: University of Minnesota Press.

[5] Doncan, R., \& Reiser, B., 1997, Reasoning Across ontologically distinct Levels: Students' Understanding of molecular Genetic.Journal of Research in Science Teaching, 44 (7) 938-959.

[6] Gomez, E., Benarroch, A., \& Marin, N., (2006) Evaluation of the degree of coherence found in students' conceptions concerning the particulate nature of matter, Journal of Research in Science Teaching. 43 (6) 577-598.

[7] Kang, N., "Elementary teachers' epistemological and ontological understanding of teaching for conceptual learning" Journal of Research in Science Teaching, 44 (9) 1292-1317.

[8] Nussbaum, J., \& Novak, J. "Children Conception of the Earth as a Cosmic Body," Science Education, 63, pp-83-93, (1976). 
[9] Pocovi', M., (2001), "The effects of a historybased instructional material" journal of Research in Science Teaching" 44 (1) 107-132.

[10] Posner, G., Strike,K., Hewson,P., and Gertzog, W., "Accomodation of Scientific Conception", Science Education $\quad 66,211-227,(1982)$.

[11] Shymanasky, J., Yore, L., Treagust, D., Thiele,R., Harrison, A., Waldrip, B., Stocklmayer, S., \& Venville, G., (1997). Examining the construction process: A study of changes in levl 10 students' understanding of classical mechanics. Journal of Research in Science Teaching, 34 (6) 571- 593.

[12] Smith, E., Blakeslee, T., \& Anderson, C., (1993) Teaching strategies with conceptual change learning in science. Journal of Research in Science Teaching, 30 (2) 111- 126.

[13] Strike, K., \& Posner, G., (1992) A revisionist theory of conceptual change. In R. Duschl \& R. Hilton (Eds.), Philosophy of science, cognitive psychology, and educational theory and practice (pp. 147- 176). Albany, NY: SUNY Press.

[14] Zaid, S., (1988). "Teaching for Understanding Scientific Concepts and Principles: Teaching the Biochemical Activity of the Cell Using MetaProcedural Reorganization" Unpublished Dissertation, M.S.U. 